rabbit and other animals which act as radiators. Tho location of fat deposits in the tail or rump of desert sheep and in the hump of Zebu cattle and the camel also allows of the dissipation of heat as compared with the uniform subcutaneous layer of fat of temperate breeds which acts as an insulator against cold.

Throughout, many experimental methods of investigating the problems of heat and water losses by the body in different species are described and a large number of references to original papers are quoted. These should be most useful to those who are investigating these problems in man and domestic animals. One requires to know for each species the main avenues for water loss and the partition of the loss between the different avenues under different conditions of environment. Among the larger animals, the main method used to cool the body is water evaporation, either by sweating in man and the horse or by panting and increasing respiration rate in cattle and sheep. In the smaller animals such as rodents, however, other methods must be used, for an animal of $100 \mathrm{~g}$ would have to use some 15 per cent of its bodyweight per hour to be effective for this purpose.

The evasive action taken against high temperatures by the different species of the smaller animals varies. Some rodents live underground by day and come out to feed only at night when temperatures are lower. Many small birds feed only in the early morning and rest in the shade by day. Larger birds escape heat by hoverir. $g$ at about $1,000 \mathrm{~m}$ during midday hours. Another method adopted by some animals, such as certain ground squirrols and pocket mice, is that of spending late summer and early autumn in æstivation, which may occur at temperatures as high as $25^{\circ} \mathrm{C}$. Body temperatures drop to within $1^{\circ} \mathrm{C}$ of ambient temperatures, with consequent reduction in metabolic rate and water conservation. The possible physiological causes which initiate æstivation, such as deprivation of food, are discussed.

Incidentally, the breeding season of many desert birds is controlled by the amount of rain. During a drought period the gonads are of minimal size, but after a good rain ovulation occurs within two weeks. It would appear that the ancestrous condition is due to lack of nutrition rather than the absence of gonadotrophic hormones. JoHN Hammond

\section{PIONEERING PREHISTORY}

The Abbé Breuil, Prehistorian, a Biography

By Alan Houghton Brodrick. Pp. 256. (London: Hutchinson Limited, 1963.) $30 s$.

Y T was a sad day for prehistorians all over the world when the news came that the father of the subject, the Abbe Breuil, had died. His influence had penetrated throughout the whole range of the study. It was not merely that he had rehabilitated the Aurignacian culture and placed it in its proper sequence, or that he had determined the Quaternary succession of gravels in the Somme valley, but that there was scarcely any branch of prehistoric archæology on which he had not left his mark. More particularly will he be remembered for his work on both the cave art and home art of prehistoric man. $\mathrm{He}$ himself was a first-class artist as well as a man of scientific accuracy, and he lived at a time when the painted caves of Southern France and Northern Spain were being discovered. There is scarcely one of them where he has not faithfully copied and published the Upper Palæolithic art found on their walls.

As his first foreign pupil, I had known him well since 1912 and travelled and worked with him widely both in Spain and in France. His interests ranged beyond the Palæolithic period, and actually, while in Spain, we were largely engaged in copying the Copper Age rock shelter paintings which abound in parts of the Iberian Peninsula. Later, after I had been in South A.frica myself, I was able to introduco him to the South African scene at the time of the meeting of the British A.ssociation there in 1928; and when France was invaded in the Second World War, after a sojourn in Portugal, he again visited that country. $\mathrm{He}$ has left his mark on prehistoric studies there, as local prehistorians such as the late van Riet Lowe and John Goodwin were the first to acknowledge.

Alan Brodrick has written a very interesting book. $\mathrm{He}$ is not only concerned with the details of what Breuil did for his subject: he is also concerned with the man himself. Born in a professional milieu-his forebears were lawyers and the like-of a Picardy family which may in the remote past have had some Spanish blood in its veins, he was brought up at Clermont-sur-Oise, some forty miles from Paris. Breuil was always a sincere Christian and a Catholic, and it is not surprising that he became a priest, though actually he never had a cure of souls. A faithful son of the Church, he had also the esprit ouvert and personal philosophy without which he could not have been the great prehistorian he was-we often talked about the problems of religion when the day's work was done. Brodrick traces his early life and the influences that affected him. He was ordained Priest at St. Sulplice in 1900 , but the call of prehistoric studies drew him more and more towards his life's work. Brodrick deals with his early studies in the field both in France and Spain and his work with his collaborators in the subject, the Abbé Bouyssonie and tho older man, Cartailhac of Toulouse. When Prince Albert of Monaco founded the Institute of Human Palæontology in Paris, it was natural that Breuil and his friend and colleague Hugo Obermaier became its two first professors. A.nother colleague with whom he worked was the Comte Bégouen, who owned a château in the Ariège (Pyrenees) and on whose land are such famous caves as the Tuc d'Audoubert with its clay bisons and the Trois Frères with its painted and engraved sorcerer. Breuil studied, traced and published both these unique sites. Another colleague was the well-known Teilhard du Chardin, who worked for some time at Choukoutien in China.

It was obviously impossible for even a man like Breuil never to make a mistake, and he may well have been wrong in suggesting a very early date for the so-called 'White Lady' of South-west Africa. Again, as I believe he recognized at the very end of his life, all the art in the cave of Rouffignac may not be false. There may be some genuine prehistoric drawings, with many that are undoubtedly modern. But what was wonderful in working with Breuil was to see his extraordinary intuition in action-and practically always in the long run it proved right. Always a valued visitor in England, I am proud that my University of Cambridge recognized his contribution to learning by giving him an honorary doctorate so early as 1920.

Brodrick's biography gives a vivid picture of the man, kindly, intelligent, indefatigable, stimulating: one who has left his mark on his generation. It can be very warmly recommended.

There is a final little detail which I should like to put on record. When Northern France was invaded by the Germans during the Second World War, Breuil was in the south of the country. Finding some information which he thought the friends of France should know about he sent me a post-card with some doggerel Latin verses, headed "from a newly discovered manuscript of Ovid for your Latinists". His Latin contained phrases he knew would mean something to me. I "twigged" and sent the post-card to Intelligence. For two months I heard nothing; then came a laconic reply: "If your friend has any more of his verses we should like to see them"! It was typical of Breuil's skill and intuition to write it all on an open post-card so that the censor, who probably didn't understand Latin anyhow, would not imagine that the verses could contain information about an under. ground bomber factory! M. C. BURKITT 